\title{
Participatory Oriented Method in Developing Tourism Village of Mendak Madiun
}

\author{
Maria Magdalena Widiantari*, Fikri Hasan \\ Communication Science Dept. \\ Merdeka Madiun University \\ Madiun, Indonesia \\ *mariamagdalena@unmer-madiun.ac.id, fikri@unmer- \\ madiun.ac.id
}

\author{
M. Arif Bakhtiar Effendy \\ Civil Engineering Dept. \\ Merdeka Madiun University \\ Madiun, Indonesia \\ arifbakhtiar333@gmail.com
}

\begin{abstract}
In 2017, Madiun Government had been prepared Madiun Tourism Development Master Plan as the main guideline for planning, management and control of tourism development at the district level. It contains vision, mission, objectives, policies, strategies, plans, and programs that need to be carried out by stakeholders in tourism development. The aim of this paper is to contribute to the understanding of community participation in tourism development by examining the fundamental character of the local communities of Mendak, how local communities participate in tourism development, and the right strategy to drive the participation of local communities based on their fundamental character. A stratified and convenience sampling approaches was used to select the sample of 706 households. First, the population of Mendak was subdivides into three sub villages, and then convenience sampling was applied through the selection of each household in the three sub villages. The finding revealed that the local government of Mendak requires assistance in mobilizing the participation of the local communities. The local communities also want to be part of tourism decisions, through FGD as the method of participation.
\end{abstract}

Keywords: participation oriented, local comunities, tourism village

\section{INTRODUCTION}

The masterplan of Madiun Tourism Development have been prepared the following stages of activity arranged for five years since 2917, namely: (1) 2018: preparing the community and other stakeholders to get involved on the acceleration of tourism development program; (2) 2019-2023 : a. Strengthening and developing the existing potential tourism through the development of thematic tourism destination; $b$. Developing the accessibility, tourism facilities, national and international standard of public's infrastructure facilities; c. Developing tourism networks with other tourism destinations in Indonesia; d. Marketing and promoting local tourism based on information technology; (3) 2024-2025 : a. National and international tourism market expansion; b. Developing the international tourism network [1].

The initial stage as stated in the masterplan was the preparation of the community and tourism stakeholder in order to accelerate tourism development. Thus, it could be interpreted that the community's role would be an important aspect in realizing a tourism destination development [2]. As we know that the development of tourism renders various economic, socio-cultural, and environmental changes on the host of community's life, some more beneficial than others. Thus, local community's participation seems to be an imperative for the sustainability of the tourism at any destination [3].

Participation is the involvement of local community members in making decisions start with planning process. Participation of local people is a criterion often agreed on as an essential condition for development and sustainability of any form of tourism [4]. Generally, local community participation is easy to plan, but the implementation is not as easy as imagined. However, local people certainly want to play a role in every stage of development from planning, implementation, to supervision. The ideal would be for communities to decide the form and function of tourism developments and have full control over any tourism schemes in their location. In most cases, local residents often lack the experience, resources and hence even interest, needed to establish successful tourism ventures [5]

Mendak Village, a sub district of Dagang, Madiun Regency, Indonesia have been developing Watu Rumpuk as tourism destination now. To develop this new tourism destination, the local community participation was needed so that the development process can be carried out quickly. This paper aimed to examining the fundamental character of Mendak's local communities, how they had participated in tourism development, and the right strategy to drive their participation. All of this research questions will be concluded as the understanding of local community participation in developing tourism destination.

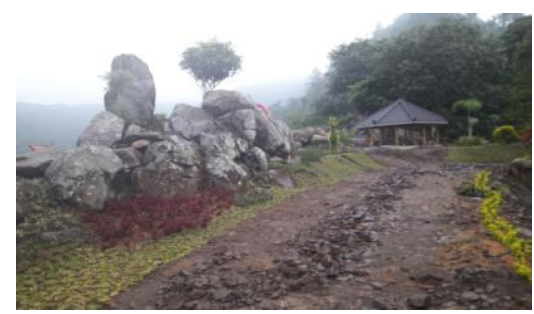

Fig. 1. Watu Rumpuk : A big pile of stones. 
Figure 1 shows the initial conditions before Watu Rumpuk was developed into a tourist destination. Before it was developed, Watu Rumpuk was a forest area where there were large piles of boulders that looked exotic and interesting to be used as tourist attractions.

The idea to build a tourist site was initiated by the village head of Mendak, At the initial stage the plan did not receive community support, so the Mendak village head had to work hard to realize this plan. Why did the community not support this plan? This is the question in this study. This is important to know because community involvement still needed to continue the development of this Watu Rumpuk tourist site.

The existing condition of Watu Rumpuk has now become a tourist park visited by many local tourists and continues to be developed by adding various natural tourism attractions.

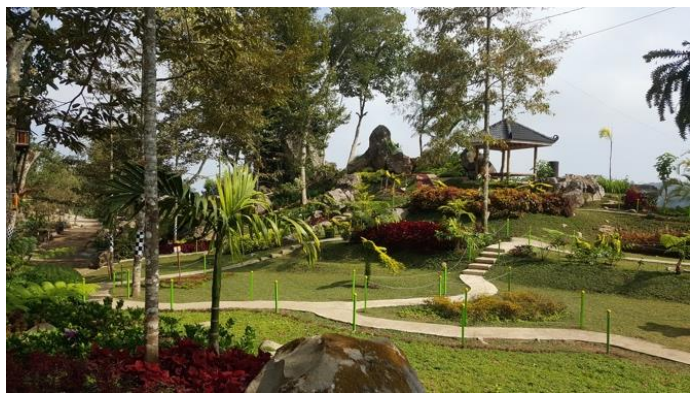

Fig. 2. The existing condition of Watu Rumpuk park.

The Mendak village government still needs community support to develop and manage Watu Rangkas tourist sites so that its existence provides greater benefits for the community, both economically and socio-culturally.

The selection of research location was based on the consideration of the uniqueness in the Watu Rangkas tourism development process. Mendak is a village with a smallest area and less population in Madiun Regency. But Mendak has been able to develop tourist destinations well enough even though the quality of human resources of the local community is not better than the people in the surrounding area. Therefore, this research conducted to look at how community participation could be built according to the basic character of local communities.

\section{LITERATURE REVIEW}

\section{A. Participation Concept}

In many developing countries, including in Indonesia, development processes do not involve local communities. They are only the object of development, not the subject of development actors yet. Many government policies were decided top-down which ultimately did not meet the target. Likewise, the development of tourism. In many places, it was conducted by private institution so that local people could not feel the benefits. This development paradigm will cause problems in the future.

Richards and Hall argue that if the local community was not involved from the initial planning stage of tourism it becomes much harder to bring them on board at a later stage.
The local community might have some resentment at not having been part of the process from the start [6]. It is believed that only when local communities are involved in tourism management their benefits can be ensured [7], and their traditional lifestyles and values respected [8].

There are many benefits that can be obtained by involving local communities in development activities. Development actors can get any information about the values that apply in the community, know the views of the community about what is needed, even get support. Likewise, with tourism development, the involvement of local communities will guarantee a faster and smoother development process because of the support of local communities.

The concept of participation has broad and varied meanings, but it can be explained briefly that participation is the involvement of the community in an activity starting from planning, implementation, to supervision so that the activities carried out have a maximum positive impact on the interest of community.

Adapted from Pretty and Cornwall, community participation including all activities such as: (a) Active involvement in all stages; (b) Self-mobilization; (c) Shared decision making; (d) contribution of resources; (e) ownership; and (d) right to participate [9].

Based on the involvement in activities, participation in term classified into two kinds, namely direct and indirect participation. Direct participation refers to the individual present and participates in activities directly in discussing program. While indirect participation refers to the views, ideas, or involvement in discussing the program with others or delegates the participation to others. Local communities' participation ranges from a passive position at one end of the spectrum to one of self-mobilization that is characterized by independent initiatives where local people are strengthened socially and economically by their involvement. Lekaota notes that the basic requirement for the community approach to tourism development is that all members of communities in tourist destination areas, rather than just those directly involved in the tourism industry, should be involved in the management and planning of tourism [4].

Cohen and Uphoff, distinguish participation into four types, namely: (1) Participation in decision making, relating to the determination of alternative ideas or ideas concerning common interests, in the form of giving opinions, ideas, responses in the form of support or rejection expressed in meetings or discussions, (2) Participation in program implementation is the activity of mobilizing resources, funds, administrative activities, coordination, and program description, (3) Participation in taking benefits, related to the utilization of program achievement results both in quantity and quality that can be seen from an increase in output and the percentage of program success, (4) Participation in evaluation involves evaluating the overall program implementation to find out the suitability of program achievements with planning [10].

The most popular participatory development method is FGD or Focus Group Discussion, a data collection method commonly used in qualitative social research. With this 
method, the acquisition of data or information is done through discussions conducted by group members to solve a problem, where group members interact and participate through opinions or ideas to reach an agreement on a solution or action to be taken together.

One of the advantages of using the FGD method is that the various responses that arise during the discussion process provide more data and information that cannot be obtained by other data collection methods, especially in quantitative research FGD has a number of characteristics, among them, a method of collecting data for this type of qualitative research and the data generated comes from the exploration of social interactions that occur when the discussion process conducted by the informants involved. The main strength of the FGD method is the ability to use interaction between participants to gain depth and wealth of denser data that is not obtained from the results of in-depth interviews [11].

In developing and encouraging community participation efforts in development, various stages of analysis and methods are used so that appropriate methods and strategies are found based on the character of the community and program objectives.

\section{B. Strategic Extension Campaign (SEC)}

Strategic Extension Campaign (SEC) is a method that promotes community participation, strategic planning, systematic management, and implementation in the field. This method was developed by FAO (Food and Agriculture Organization) and has been applied in several countries in Africa, Asia and Latin America, especially in the development and training programs in agriculture.

The SEC program refers to a system approach that begins with a Knowledge, Attitude, and Practice (KAP) survey of farmers whose results are used as input in planning and as a basis for evaluation. Based on the experience of the application of the SEC in the development of agricultural programs in many developing countries, all show increased effectiveness and efficiency because the SEC emphasizes problem solving orientation, participatory planning approaches, training for actors, developing multi-media materials, and developing management procedures, monitoring, and evaluation [11]

Some characteristics of the SEC method that make the implementation of a program more effective and efficient are include: (a) Participatory planning approaches, (b) Needs oriented and driven by demand, (c) Using strategic planning and integrated systems approaches, (d) Considering the human dimensions and behavioral dimensions, (e) Problem solving oriented, (f) Using a cost effective multi-media approach, (g) Providing training and supporting materials, (h) Documented process and evaluation procedure, (i) Can be applied to development programs in other fields [11].

SEC activities such as surveys, strategic planning and management, development and design of multimedia, training, field implementation, monitoring and evaluation are integrated systems. This activity does not ignore the human dimensions and behavioral dimensions such as socio-psychological, socio- cultural, and socio-economic factors that can support the process of adopting innovation.

This method emphasizes problem solving that allow people to adopt new innovations. Therefore, this method selects, prioritizes, and utilizes the most relevant and important information or facts to maximize efforts and minimize the problems that have been identified through previous surveys. The classification of problems, goals, strategies and information needed is based on the level of knowledge, attitudes, and behavior of the target audience so the recommendations given are not only conceptually important but also practical.

The aim of this study was to find: (1) The basic character of Mendak community related to their participation in development, (2) The appropriate SEC (strategic extension campaign) strategy in developing the concept of a tourism village, and (3) The right method for mobilizing the participation of Mendak community in developing tourism villages.

\section{METHOD}

This study used multi-methods approach where some research questions had been answered using qualitative methods and another questions had been answered quantitatively.

A stratified and convenience sampling approaches used to select the sample of 706 households. First, the population of Mendak was subdivides into three sub villages, and then convenience sampling was applied through the selection of each household in the three sub villages.

This research started with KAP (Knowledge, Attitude, Practice) survey to find out public knowledge about tourism, and followed with ex post facto research related to community involvement in planning, implementation, and supervision of the Watu Rumpuk tourism development program and the obstacles might arise so that the community could not or did not want to participate in development process.

Likewise, in addition to participatory observation also conducted an investigative interview and document's studies. All data that had been collected then analyzed with data triangulation.

\section{FINDINGS AND DISCUSSION}

Participatory approach is seen as a responsive method because it is carried out based on the results of a survey of knowledge, attitudes, and what the community does. This approach is easily accepted and relevant to be applied because it leads to what is needed and which is the main concern of the community by exploring the community's original knowledge, value systems and beliefs about the problem or program to be implemented which may actually be good, but needs to be improved.

\section{A. Socio-Cultural Characteristics of Society}

Demographically, the composition of the population of Mendak Village is seen from the age factor, included in the 
category of young population groups which, if depicted in the pyramid table, are included in the expansive population pyramid. The characteristics of the composition of the population with the age distribution belonging to the expansive pyramid include the majority of the population is in the group of young population, the age group is slightly old, the birth rate is high, the population growth rate is also high. (see Table 1). The composition of the expansive pyramid population shows that the population of productive age is greater than the unproductive age so that it is beneficial in making decisions or public policies that are oriented to productivity and progressiveness.

From the level of education, most of the population of Mendak Village are included in the low-educated group. (See Table 2) This is a great challenge in improving the quality of human resources, including in terms of providing employment. The low level of education of the majority of Mendak community is due to economic factors and access to education locations. In Mendak Village, there is only 1 (one) educational facility, namely Elementary Schools. To continue their studies to a higher level, they must go to the sub-district city, which is about $15 \mathrm{Km}$ from Mendak, namely to Dagangan's Middle School and Dagangan's High School. Meanwhile, to continue to tertiary education level, it must travel more than $30 \mathrm{Km}$ to the city of Madiun or Ponorogo.

The low level of education affects the livelihoods of Mendak community who are mostly farmers and ranchers (cows and goats) and become Indonesian Workers (TKI) in Malaysia, Hong Kong, and Taiwan. We can see that most Mendak community face poverty issues so that empowerment is needed to accelerate welfare improvement and encourage increased education. In a greater scope, socially the people of Madiun society classified into the territory of Mataraman culture that was genetically related to the empire of Yogyakarta and Surakarta,

TABLE I. MENDAK Residents Based ON AgE

\begin{tabular}{|l|l|l|l|}
\hline \multirow{2}{*}{$\begin{array}{c}\text { Age } \\
\text { (Year) }\end{array}$} & \multicolumn{2}{|c|}{ Gender } & \multirow{2}{*}{$(\mathbf{N}=\mathbf{7 6 0})$} \\
\hline $0-10$ & 55 & 61 & 116 \\
\hline $11-20$ & 46 & 44 & 90 \\
\hline $21-30$ & 60 & 59 & 119 \\
\hline $31-40$ & 75 & 74 & 147 \\
\hline $41-50$ & 40 & 36 & 76 \\
\hline $51-60$ & 44 & 48 & 92 \\
\hline $61-70$ & 22 & 25 & 47 \\
\hline$>71$ & 10 & 7 & 17 \\
\hline $\mathrm{N}$ & 356 & 350 & 706 \\
\hline
\end{tabular}

Source: Dagangan in Numbers, 2018

A unity of Javanese, Hindu, and Islam which manifested in beliefs. The Mataraman community tends to be influenced by the culture of the royal court, and holding strong family values.

Religiously, United States researcher Clifford Geertz described that Mataraman community have an "abangan" character, that is not very strong in holding ideology or religion and is very open in accepting any ideology, tends to be rational and not easily influenced by a new ideology, does not like things that are striking both in attitude and appearance.
Herusatoto identified the Javanese philosophy of life that characterizes most of the Mataraman community as follows:

The philosophy of life of the Javanese is first endeavoring to open the mystery-covered path of understanding towards the clarity of reality. Second, think deeply about each symptom to be questioned, so as to arrive at conclusions that are general and universal. Third, look for clarity between cause-effect relationships. Fourth, using a system and method to solve a problem of live. Fifth, hard effort in solving problems and look for lives' goals [12].

The philosophy is then explained briefly that the Mataraman community has a character of willingness (nrimo), patience, prioritizing good character, and prioritizing the public interest as a result of rational thinking that is not easily influenced.

Based on interviews, observations, and documentation studies, it is known that Mendak people seem to have a cultural capital that supports participation in development. The character is manifested in the form of mutual cooperation, kinship, prioritizing the public interest, and the beliefs that everything that is done together will produce something that can be used together. This can be seen from the tradition of community service to improve public facilities, mutual cooperation, including activities such as the commemoration of Indonesian Independence Day, and various other activities. However, based on the results of the documentation study, the results of the meeting, and the FGD conducted in the framework of preparing the Watu Rumpuk tourism development plan and the development of the Mendak tourism village, it is known that the participation rate is relatively low, the information conveyed by the village administration tends to be top down where the concept, design, and tourism location scheme is well structured and only submitted in meetings to get the residents' approval.

TABLE II. MENDAK RESIDENTS BASED ON EDUCATION

\begin{tabular}{|l|l|l|}
\hline No & \multicolumn{1}{|c|}{ Level of Education } & $(\mathbf{N}=\mathbf{7 6 0})$ \\
\hline 1 & Not Yet / Not / Has Not Going To School & 194 \\
\hline 2 & Elementary School & 307 \\
\hline 3 & Yunior High School & 125 \\
\hline 4 & Senior High School & 65 \\
\hline 5 & Sarjana & 15 \\
\hline N & 706 \\
\hline
\end{tabular}

Source: Dagangan in Numbers, 2018

While in the meeting notes it is known that the input or opinions of residents do not exist, only questions asking for an explanation of the concept of tourism to be built and technical steps to be taken.

\section{B. Knowledge, Attitude and Practice (KAP) Survey}

Before reviewing the participation of Mendak residents in developing of Watu Rumpuk tourist destination and Mendak tourism villages, we conducted a KAP survey to find out to what extent the community knew, understood, and supported the governments' program related to the tourism village to 60 respondents spread over 6 RTs using random techniques sampling. 
1) Knowledge: To find out whether respondents have adequate knowledge about tourism, they are asked about the components of tourism and the concepts of tourism. From Table 3 we know that the respondent's knowledge of tourism and tourism concepts can be said to be sufficient to participate in the development of Watu Rumpuk tourism and the development of the Mendak tourism village.

2) Attitude: To find out the respondent's attitude towards the Mendak Village Government program in the development of Watu Rebar tourism and the development of Mendak tourism village, the question is given whether the respondent approves, supports, and wants to participate in tourism development. From Table 4 we can find supportive attitude and willingness to participate is sufficient to participate in the development of Watu Rangkas tourism and the development of Mendak tourism village.

3) Practice: The next question is related to community involvement in the implementation of Watu Rump tourism development, from planning to implementation to managing and utilizing the results. In Table 5 we can see the respondents involved in the Watu Riles tourism development and development program starting from planning, implementing, managing, to utilizing fewer results than those not involved. This shows the low participation of the community in the construction of Watu Rangkas tourism and the development of the Mendak tourism village.

TABLE III. RESPONDENTS' KNOWLEDGE OF TOURISM

\begin{tabular}{|l|l|l|}
\hline No & \multicolumn{1}{|c|}{ Categories } & \multicolumn{1}{c|}{$(\mathbf{N = 6 0 )}$} \\
\hline 1 & Very Low & 4 \\
\hline 2 & Low & 12 \\
\hline 3 & Medium & 26 \\
\hline 4 & High & 18 \\
\hline N & 60 \\
\hline \multicolumn{2}{|c|}{ Source: Questionnaire No. 1-10 }
\end{tabular}

\section{The Implementation of Strategic Extension Campaign} (SEC)

In the process of developing Watu Rumpuk tourism village, the aspect of SEC method had not fully implemented. Village.

TABLE IV. RESPONDENTS' ATtitUdes TOWARdS PROGRAM

\begin{tabular}{|l|l|l|}
\hline No & \multicolumn{1}{|c|}{ Categories } & \multicolumn{1}{|c|}{ N } \\
\hline 1 & Not Supportive, & 2 \\
\hline 2 & Less Supportive & 8 \\
\hline 3 & Supportive & 42 \\
\hline 4 & Very Supportive & 8 \\
\hline N & 60 \\
\hline
\end{tabular}

Source: Questionnaire No. 11-20

Development Planning Consultation (Musrenbangdes) activities carried out are more in the form of submitting plans and requests for community approval and support. While ideas or ideas, concept and design planning, and the appointment of implementing personnel have been designed by the Village Headmaster and a small team who later became the Watu Rumpuk Management Association.
The SEC aspect concerns on the basis needs oriented and driven by demand, and the development of Watu Rumpuk tourist destination and Mendak tourism villages is also based on the need to improve the welfare of the community through the tourism sector. This policy was taken with the consideration that Watu Rumpuk was a potential area to be developed as a tourist destination and it is necessary to create a market in order to encourage production and marketing of agricultural and plantation products as a main local product of Mendak.

The SEC aspects concerning strategic planning and integrated system approaches are seen in the blue print of Watu Rumpuk tourism development in the form of a plan outline. While the system integration and implementation stages adjust the situation and conditions, are not systematically arranged, and are more spontaneous in nature as needed. Another aspect that concerns consideration of the humanitarian dimension and behavioral dimension is seen from the selection of the Watu Rumpuk tourism management team which prioritizes Karang Taruna-youth groups- in order to provide employment and reduce unemployment, reduce juvenile delinquency and crime. This aspect also fulfills the orientation aspect in solving problems, not only the problem of prosperity, economic improvement, but also the provision of employment and reducing unemployment and delinquency of youth.

SEC aspects related to the use of a multi-media cost effective approach have not been implemented given the limited resources both human resources and other resources such as mastery of technology, the availability of hardwaresoftware, and the availability of the budget. Likewise, with the availability of training and training support materials, it was not carried out and provided by the Mendak government and team, but rather waited from other parties such as from the department, the private sector, academics, and other stakeholders. And because it is managed conventionally, the process of developing Watu Rumpuk tourism and Mendak tourism villages is not equipped with documents such as builtin process documents and evaluation procedures.

\section{Discussion}

Basically the Mendak village community has a good understanding of the development of Watu Rangkas tourism and the Mendak tourism village even though the understanding they have is more of a global understanding and an outline. In general, the community supports and has a participatory power, however in its implementation it does not involve involvement from planning, management, to evaluation.

Nevertheless, the community also felt the benefits of the development of Watu Rangkas tourist sites, including stalls for trading food, drinks, merchandise, managing parking areas and motorcycle taxi transportation services.

In case of the application of the SEC method in the development of Watu Rumpuk tourism destination, it is known that in its implementation it is not fully carried out due to several factors, including the lack of human resource capacity in terms of planning, implementation, evaluation, and monitoring so that the process of developing Watu Rumpuk tourism destination runs conventionally, spontaneous in nature 
adjusting the situation and conditions, not well documented, and advanced planning is not conceptualized in the form of planning documents.

\section{CONCLUSION}

This research shows that the SEC method in developing Watu Rumpuk tourism destination and Mendak tourism village is not fully implemented so that it is necessary to arrange the documents, procedures, and development planning in the future so that the development process can be more directed, participatory, effective and efficient.

It can be concluded that the Mendak village government requires assistance in mobilizing the participation of village communities and by looking at the character of the Mendak village community, the right method is the FGD (Focus Group Discussion) because this method is easy to implement, does not require large costs, and opportunities for the emergence of community openness in FGD greater and open opportunities for the emergence of natural ideas that reflect the fundamental character of society.

From the FGD activities also can be found original ideas, can be measured the amount of support for the programs offered, as well as measuring the level of community participation.

\section{ACKNOWLEDGMENT}

Our gratitude goes to the DRPM Ministry of Research, Technology and Higher Education who has funded this research, the Mendak village government of Dagangan Madiun and LPPM Merdeka Madiun University.

\section{REFERENCES}

[1] Bappeda Kabupaten Madiun. "Madiun Tourism Development Masterpland," Unpublished.

[2] D. Stylidis, A, Biran, J. Sit, and E.M. Szivas, "Residents' Support For Tourism Development: The Role Of Residents' Place Image And Perceived Tourism Impacts," Tourism Management Journal, vol. 45, pp. 260-274, 2014.

[3] D. Gursoy, C. Chi, and P. Dyer, "Local Attitudes toward Mass and Alternative Tourism : The Case of Sunshine Coast, Australia," Journal of Travel Research, vol. 49, no. 3, pp. 381-394, 2010.

[4] L. Lekaota, "The Importance of Rural Communities" Participation In The Management of Tourism Management: A Case Study From Lesotho". Worldwide Hospitality and Tourism Themes, vol. 7, no. 5, pp. 453-462, 2015

[5] C.M. Rogersson and T. Letsie, "Informal Sector Business Tourism In The Global South: Evidence From Maseru, Lesotho,” Journal of Urban Forum, vol. 24, no. 4, 2013.

[6] G. Richards, and D. Hall, Tourism and Sustainable Community Development. London: Routledge, 2000.

[7] R.E. Mitchell and D.G. Reid, "Community Integration: island tourism in Peru," Annals of Tourism Research, vol. 28, no. 1, pp. 113-139, 2001.

[8] P.J. Sheldon, and T. Abenoja, "Resident Attitudes in a mature destination: The case of Waikki," Journal of Tourism Management, vol. 22, no. 5, pp. 435-443, 2001.

[9] https://fic.tufts.edu/pacapsproject/CoordinationSupport/Slides/Day1/SessionParticipation_PIAfor.p df

[10] J. Cohen and N. Uphoff, "'Participation's place in rural development: Seeking clarity through specificity'," World Development, vol. 8, pp. 213-235, 1980.

[11] R. Adhikarya, SEC : A Participatory Oriented Method of Agriculture Extension. Rome Italy: FAO of United Nation, 1994.

[12] B. Herusatoto, Simbolisme dalam Budaya Jawa (Simbolisme in Javanesse Culture). Yogyakarta: Hanindita Graha Widia, 2001. 